\title{
THE IDENTIFICATION OF LEARNING NEEDS AS THE BEGINNING IN ORGANIZING EMPOWERMENT PROGRAM AT PANDHALUNGAN SOCIETY IN THE PURLIEUS OF JEMBER
}

\author{
Fuad Hasan, Linda Fajarwati, Sylva Alqornia \\ Faculty of Teacher Training and Education University of Jember \\ fuadhasan@unej.ac.id; linda.fkip@unej.ac.id; sylva.fkip@unej.ac.id
}

\begin{abstract}
In optimizing achievement of educational objective, the identification of learning needs become urgent to be conducted, especially for non formal education progam. Ths study is conducted to reveal Pandhalungan societies learning need in the purlieus of Jember. It is used qualitative approach with ethnography as its research design. The ethnography is chosen because the researcher want to describe Jember societies learning need in the purlieus which a part of Pandhalungan ethnic. This study is done by four step, it was preliminary study, deciding problem category, data collecting, and data interpretation. Data collecting is done by observation, interview, and documentation study. Data Validity is done by triangulation method and resources. This study showed that Pandhalungan societies in the purlieus of Jember have literacy, equality education, life skill, and penyuluhan as their priority learning needs.
\end{abstract}

Key words: Identification of learning needs, Pandhalungan society, purlieus of jember

\section{INTRODUCTION}

As mentioned at the opening of UUD 1945 point 4 that the government of Indonesia has objective to make its society become clever and prosperous. To realize that objective the government made some educational program that is done at formal setting starting elementary school until university and also non formal setting like training, life skill, empowerment etc.

Empowerment is a multi-dimensional social process that helps people gain control over their own lives. It is a process that fosters powers (that is, the capacity to implement) in people, for use in their own life, their communities, and in their society, by acting on issues that they define as important (Czuba and Page, 1999). By that definition we can see that there are three component of empowerment, multidimensional, social and process.

The form of empowerment program are various. It is because, the society as the object and also subject of empowerment, the potential of places they live and the social system also have various condition. We could not conduct automotive training for those who have farming as their job, we could not conduct farming training for those who do not have farm to cultivate, and we could not conduct training at the morning while they work in the morning.

Because of those reasons the identification of learning needs is become the very first step we have to do before conducting empowerment program. It is not only to know what kind of learning program that is needed by society but also to decide how deep the have to learn it and how to learn it. 
Pandhalungan is a term to call those who live on Tapal Kuda Area, but Jember become regency of Pandhalungan society after declared by Faida in 2016 (Zoebazari, 2017). There are so many interesting thing of Pandhalungan society, but here, we will focused on how they live.

The previous research has done by Sulistiani (2011) who focused on youth bummer, her finding is youth bummer learning need is to continue their education and vocational skill to full fill their basic need.

This study objective is to reveal learning needs of Pandhalungan society especially for those who live at purlieus of Jember. This study is done as a first step to conduct empowerment program at Pandhalungan Society.

\section{METHOD}

This study is conducted by using qualitative approach. This study can be categorized on interpretative approach because this study refer to description of data to be interpreted (Mapiare, 2013). This study used Ethnography design because the objective of this research is to reveal learning need at Pandhalungan society as one of ethnicity in Jember. Ethnography alone is a wide study in various social background wich have possibility to do direct observation and interview about societies activity. It also possible to do communication and interaction in the formal or informal occasion.

This study is done by four steps, field exploration, deciding problem category, data collecting, and data interpretation. Field exploration is done by analyzing the character of field where the study are going to be conducted. The result of this step is selecting Sukorambi Vilage as location of study.

The second step is deciding problem category which is done by considering the condition of field that already been decided. The considering process is done by collecting information and also doing permission to the official of Sukorambi village.

Data collecting is done by observation, interview, documentation study and also focus group discussion. Documentation study become basic data that been confirmed by the other collecting data technique.

Interpretation of data is done by analyze the data who already gathered, check and recheck and then concluding by making proportions which implement principal of logic, take it as research finding, and then compile and arrange it as complete research report.

\section{RESULT AND DISCUSSION}

Every program organizes by planning, weather structured planning or auto planning. Identification of learning needs is a part of planning program in organizing educational program. This study found that there are four learning needs that become priority of Pandhalungan society in the purlieus area of Jember. These are literacy, equality education, life skill, and counseling. Literacy become the learning need based on information from statistic data and also confirmation of some society at Sukorambi 
Vilage. Based on statistic data, Sukorambi has 1.789 people age five above who did not attend elementary school and that's probably mean that those people are illiterate people. It is also proved what Faida (the cheaf official regency of Jember) said at Antara Jatim News 2016, the number of illiterate people in Jember is 40.638.

The number of illiterate people in Sukorambi village is anonymous. Based on the result of interview to the official in Sukorambi, Sukorambi already out of illiterate people after conducting literacy program some years ago. But, based on the result of interview to the society started from they who live around official office until they who live in the border of village, they confess that they are illiterate people and all of them was follow the previous literacy program.

Literacy program is one of non formal education program which focused on eradicate illiterate people (make them literate). It is also mentioned at Peraturan Menteri Pendidikan dan Kebudayaan Nomor 86 Tahun 2014 that Literacy program is a program to make illiterate society become literate fastly. This program conducted some decade ago, but until now, there success of this program in achieving its objective is more at statistical data than the real one.

It is also happen at Sukorambi village, while the official said that Sukorambi village already free from illiterate people, our result finding shows that there are still many people who illiterate although we don't know the exact number. Munif (2014) called this phenomenon as re illiterate phenomenon. The same term also said by Pranyono (2009) which also said re illiterate people for those who are illiterate after following literacy program.

Regarding re illiterate phenomenon, Pranyono and Munif said difference causes. Pranyono (2009) said that the cause of re illiterate people is the difference method that is used by Dinas Pendidikan and Badan Pusat Statistic (BPS) in counting it. BPS used survey method while Dinas Pendidikan used actual counting by name by address. Munif (2014) said that the are seven major causes of re illiterate phenomenon, these are (1) educator did not get training before teach illiterate people, (2) educator did not make learning plan, (3) educator did not do analyze about learner back ground, (4) the limit of learning facilities and infrastructure, (5) incomplete learning time, (6) do not conduct assessment, and (7) use conventional learning process. Munif also said that the low quality of tutor become the biggest cause of this phenomenon.

About re illiterate phenomenon at Sukorambi village, the people confess that they just follow the program one until three time only. The reason why they did not attend the program until finish is because they did not realize that they need this program. To them, earn money to life is much better than attending the class It is clear that based on the process it is the major causes who make them still illiterate. They have the wrong mind set about literacy competency. Hasan (2017) said this cause as mind set problem, and it is the most serious problem that is needed to be solved soon.

The second learning need is equality education. Located at the purlieus area of Jember, Sukorambi village can be said as left behind in the education sector. Based on BPS data at 2016. There are 2.179 people who did not achieve elementary certificate, 
4.389 who only have elementary certificate, 947 people who have junior high school as their highest certificate, 608 people who have senior high school as their highest certificate, 22 people who have diploma as their highest certificate, 61 people have graduate certificate and 5 people who have master certificate.

By those condition we can conclude that people in Sukorambi village need equality education as their learning need. It is also confirmed by the official that their society need even some also have taken equality education in order to have certificate which is admitted equal with formal school certificate. They took it because it is become one of requirement to get a better job.

Based on Undang-undang Republik Indonesia Number 20 Years 2003 about National Education System Clause 26 sub clause 3 point 4, equality education is one of non formal education program which organize general education that equal with elementary school/Islamic elementary school, junior high school/Islamic junior high school, and senior high school/Islamic senior high school through Paket A, B and C program. This program is categorized as substitute of formal education.

This program is organized for those who have their own problem that make them could not attend formal school. The common reason people join equality program are (1) the age was not at its education level and (2) drop out. The age of those who attend formal school are homogeneous, so for those who did not continue or delay their school 3 or 4 years after their graduation will not able to enter into the formal school. For those who drop out or hive high possibility to drop out from formal school usually choose to enter into equality program because they do not want to delay their graduation.

The Third learning need is life skill. This need is based on data of educational level and economic level and type of work of Sukorambi society. Just like mentioned at the previous paragraph, Sukorambi society have low level of education and it also impact on their number of income and their type of work. Data about economic level show that there are 1.464 household or 5.178 people listed as poor society. And based on type of work, there are 4.617 people are freelance and 1.880 people are unpaid worker like house wife etc. based on those data, we assume that they need life skill that can be used to improve their quality of life. The program that provide skill that can be used to improve their quality of life called life skill education program.

Based on Undang-undang Republik Indonesia Number 20 Years 2003 about National Education System Clause 26 sub clause 3 point 1, life skills education program is education that provide personal skill, social skill, intellectual skill and vocational skill for work or become entrepreneur. The form of life skill education is various which also affected by the potency of village or the place where the society live.

There are so many kind of life skill that potential to be organized for Sukorambi village. Because Sukorambi located not far from the center of town. It is because almost there is nothing that can not be sold at town. But, the life skill program still have to be match with learners potential and location potential. 
The fourth learning need is counseling. This learning need is based on the major type of work in Sukorambi village. Agriculture become the major type of work and the rest are at industry/craft, construction, selling, transportation and unclassified sector. The data said that 1.328 people work at agriculture, 61 people work at industry/craft, 218 people work at construction sector, 8 people work at transportation sector and 172 people work at unclassified sector.

Sukorambi have wide fertile farmland and more than a half of their society work at agriculture sector. Sukorambi also have active farmer group. The farmer group is formed to make them easy to coordinate about farming issues with their group. The other data showed that Sukorambi people are low at education or we can say that there is no one who expert in farming looking from the educational back ground. That is why Sukorambi people need a new knowledge and new skill that can be implemented to increase their productivity. It is also confirmed that Sukorambi village has become object to implement the new knowledge from university by organizing society services program.

\section{CONCLUSION}

Identification of learning is a very first step to organize empowerment program. Pandhalungan society in the purlieus area of Jember have literacy, equality education, life skill, and counseling as their learning need. Literacy program is needed because of re illiterate phenomenon. Equality programed is needed based on the low of educational level. Life skill is needed based on educational level and economic level and type of work, and counseling need is needed based on the major type of work of Sukorambi society. All of program that will be conducted must use transformative approach, so that the objective of program can be achieved maximally.

The suggestion of this research is (1) the government should organize literacy program by using transformative learning approach (2) the government should organize equality program based vocational, (3) the government should organize life skill program based on local potention, and (4) the government should conduct agriculture counseling.

\section{REFERENCES}

Czuba, C. E \& Page, N. 1999. Empowerment: What is It?. The Journal of Extension Volume 37 Number 5 Comentary 5Com1 Oktober 1999

Hasan, F. 2017. Model Pembinaan Transformatif untuk Program Pembinaan Karang Taruna. Jurnal Pancaran Pendidikan Volume 6 Nomor 1 Hal. 179-192, Februari 2017

Munif, E. A. 2014. Fenomena buta aksara kembali di Dusun Kreweh Desa Gunungrejo Kecamatan Singosari Kabupaten Malang, perspektif fenomenologi Weber. Universitas Negeri Malang: Malang 
Mapiare, A. 2013. Tipe-tipe Metode Riset Kualitatif Untuk Eksplanasi Sosial Budaya Dan Bimbingan Konseling. Elang emas Bersama Prodi Bimbingan Dan Konseling Fakultas Ilmu Pendidikan Universitas Negeri malang

Peraturan Menteri Pendidikan dan Kebudayaan Republik Indonesia Nomor 86 Tahun 2014. Pedoman Penyelenggaraan Pendidikan Keaksaraan Dasar. Jakarta

Prayono, F. E. 2009. Buta Aksara kembali Selalu Menghantui. Online; http://fauziep.com/ancaman-buta-aksara-kembali-selalu-menghantui/ accesed 24 November 2018

Solichah, Z. 2016. Puluhan Ribu Warga Jember Masih Buta Aksara. Antara Jatim Online https://jatim.antaranews.com/berita/185975/puluhan-ribu-warga-jembermasih-buta-aksara accesed 24 November 2018 accesed 24 November 2018

Sulistiani, N. 2011. Identifikasi Kebutuhan Belajar Gelandangan Remaja di Kawasan Pasar Johar Semarang. Universitas Negeri Semarang:Semarang

Undang-undang Republik Indonesia Nomor 20 tahun 2003. Sistem Pendidikan Nasional. Jakarta

Zoebazary, M. I. 2017. Orang Pandhalungan, Pengayam kebudayaan di Tapal Kuda. Paguyuban Pandhalungan Jember: Jember 